\title{
Oxford Public International Law
}

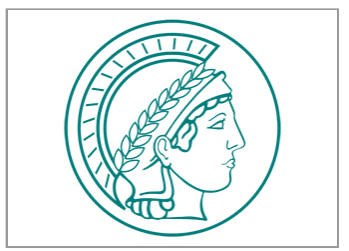

\section{North Sea Continental Shelf Cases}

Alex G. Oude Elferink

Content type: Encyclopedia entries

Product: Max Planck Encyclopedias of International Law [MPIL]

Module: Max Planck Encyclopedia of Public International Law [MPEPIL]

Article last updated: September 2013

\section{Subject(s):}

Continental shelf - Boundaries - Treaties, entry into force - Treaties, ratification - Treaties, reservations and declarations - Treaties, effect for third states - Customary international law - Equity Published under the auspices of the Max Planck Foundation for International Peace and the Rule of Law under the direction of Rüdiger Wolfrum. 


\section{A. Introduction}

1 The North Sea Continental Shelf Cases (Federal Republic of Germany v Denmark; Federal Republic of Germany v Netherlands) ('North Sea Continental Shelf Cases'), decided in 1969, were the first cases concerning the delimitation of maritime zones seaward of the $\rightarrow$ territorial sea. Some twenty cases have followed since then $(\rightarrow$ Maritime Delimitation Cases before International Courts and Tribunals). The judgment of the $\rightarrow$ International Court of Justice (ICJ) in the North Sea Continental Shelf Cases looks in detail at the role of equidistance in the delimitation process and pronounces itself on the rules and principles applicable to the delimitation of the $\rightarrow$ continental shelf as well as the factors to be taken into account. All these themes have figured to a greater or lesser extent in subsequent maritime delimitation cases.

2 The North Sea Continental Shelf Cases were concerned with the delimitation of the $\rightarrow$ continental shelf between the Federal Republic of Germany ('Germany') and respectively Denmark and the Netherlands. Germany had started bilateral negotiations with the Netherlands and Denmark in 1964 (see $\rightarrow$ Negotiation). In both cases, agreement was reached on a partial continental shelf boundary of some 25 to 30 nautical miles, respectively through a treaty of 1 December 1964 between Germany and the Netherlands and a treaty of 9 June 1965 between Denmark and Germany. Both treaties mainly applied the equidistance method to delimit the boundary. The parties could not reach agreement on the delimitation of their continental shelf seaward of the end points of these bilateral treaties. Denmark and the Netherlands considered that their entire boundary with Germany had to be delimited by application of the equidistance method. This approach would have left Germany with a more limited area of continental shelf than its two neighbours.

Germany argued that due to the concave configuration of its coastline the application of the equidistance method would lead to an inequitable result ( $\rightarrow$ Equity in International Law). Subsequent negotiations soon proved that a negotiated solution would not be possible in the short term. Trilateral negotiations focused on the submission of the dispute to thirdparty settlement and the questions that would have to be decided in such a procedure.

\section{B. The Judgment of the Court}

3 Two special agreements, one between Germany and Denmark and the other between Germany and the Netherlands, to submit a case to the ICJ were signed on 2 February 1967. Both agreements asked the Court to decide '[w] hat principles and rules of international law are applicable to the delimitation as between the Parties of the areas of the continental shelf in the North Sea which appertain to each of them beyond the partial boundary' already determined (Art. 1 (1) Special Agreement between the Governments of Denmark and the Federal Republic of Germany and Special Agreement between the Governments of the Federal Republic of Germany and the Netherlands ['Special Agreement']). The parties agreed to delimit their continental shelf by agreement in pursuance of the decision of the Court (Art. 1 (2) Special Agreement). Germany was to present its pleadings first in both cases. The parties agreed that the order of presentation was without prejudice to any question of burden of proof (Art. 3 Special Agreement). A tripartite protocol, signed on the same day as the special agreements, provided that the parties would ask the Court to join the cases and that for the purpose of the appointment of a judge ad hoc Denmark and the Netherlands should be considered as being parties in the same interest. The Special Agreements and the protocol were filed with the registry of the Court on 20 February 1967. After two rounds of written pleadings in 1967 and 1968, oral hearings took place between 23 October 1969 and 11 November 1969. The Court joined the proceedings in the two cases by an order of 26 April 1968. Although the cases remained separate, the Court observed that the legal arguments of Denmark and the Netherlands were substantially identical and were presented in common or in close cooperation. The Court found that to this extent the 
two cases might be treated as one. The Court issued a single judgment in respect of the two cases on 20 February 1969.

4 The judgment of the Court first deals in two paragraphs with the contentions put forward by Germany that the delimitation of the continental shelf should give the States involved a just and equitable share. The Court found that this doctrine ran counter to the basic concept of continental shelf entitlement. The rights of the coastal State over the continental shelf that constitutes a natural prolongation of its land territory exist ipso facto and ab initio. The process of delimitation is essentially one of drawing a boundary between areas that already appertain to one or the other State concerned.

5 Most of the judgment deals with the contentions of Denmark and the Netherlands. Both States maintained that the equidistance-special circumstances rule was applicable to their delimitations with Germany, either as a rule of conventional or $\rightarrow$ customary international law. Denmark and the Netherlands interpreted the special circumstances provision restrictively and submitted that there did not exist special circumstances in the North Sea that would require not applying the equidistance method. The Court rejected that the Geneva Convention on the Continental Shelf ('Continental Shelf Convention') had become binding on Germany. The Court found that only the existence of a situation of $\rightarrow$ estoppel could have led to this result, but there was no evidence whatever of this in the present case.

6 The Court examined three arguments of Denmark and the Netherlands concerning the customary law status of the equidistance principle. One argument started from the proposition that the right of the coastal State over the continental shelf is based on appurtenance to the land territory. The test of appurtenance according to Denmark and the Netherlands must be expressed by proximity; all parts of the continental shelf closer to one State than another State must be considered to be appurtenant to the former. Only a boundary established on the basis of the principle of equidistance would achieve this. The Court noted that appurtenance had been expressed in the literature and $\rightarrow$ State practice by a rather vague and general terminology, such as for instance 'near', 'close to its shores' or 'adjacent to'. The Court found that there was no necessary, and certainly no complete, identity between the notions of proximity and adjacency, the latter term being the most frequently used. More fundamental than the notion of proximity was the notion of natural prolongation of the land territory. Whenever a given area does not constitute a natural or the most natural extension of the land territory of a coastal State, it cannot be regarded as belonging to that State, even if it may be closer to that State than to any other State. The Court observed that a review of the genesis and development of the equidistance method confirmed its conclusions on this point. At no time was the notion of equidistance entertained as an inherent necessity of the continental shelf doctrine. On the contrary, two concepts contained in the Truman Proclamation issued by the United States in September 1945 had underlain all the subsequent history of the subject: delimitation by agreement and delimitation in accordance with equitable principles.

7 A second contention of Denmark and the Netherlands was that Art. 6 Continental Shelf Convention embodied an already existing rule of customary law. The Court concluded that the drafting history of Art. 6 Continental Shelf Convention did not support such a contention. This conclusion was found to be significantly confirmed by the fact that Art. 6 Continental Shelf Convention is one of those which allowed for reservations ( $\rightarrow$ Treaties, Multilateral, Reservations to). This cannot be the case for general or customary law rules and obligations. 
8 The Court also rejected the last part of the argument of Denmark and the Netherlands that the equidistance principle had become a rule of customary law since the adoption of the Continental Shelf Convention. In this connection, the Court noted that this process is not to be regarded as having been attained lightly, and set out conditions that would have to be met. The provision concerned should be, at all events potentially, of a fundamentally norm-creating character such as could be regarded as forming the basis of a general rule of law. The Court admitted that the equidistance principle might be said to fulfil this requirement in abstracto. However, the form in which it was embodied in Art. 6 Continental Shelf Convention and its relationship to other provisions of the convention made this conclusion open to doubt. The Court referred to the primary obligation to effect delimitation by agreement, the part played by special circumstances and the faculty of making reservations to Art. 6 Continental Shelf Convention. The fact that the Court referred to the 'very considerable, still unresolved controversies as to the exact meaning and scope' of the notion of special circumstances suggests that the Court was very much aware of the fact that neither the drafting history of Art. 6 Continental Shelf Convention nor State practice would have assisted it in elaborating this notion. The Court in its judgment points out that its findings on equidistance make it unnecessary to determine whether or not the German North Sea coast forms a special circumstance.

9 According to the Court, a further requirement for the formation of a rule of customary law would be that State practice, including that of States that were specially affected, should have been virtually uniform in the sense of the provision invoked and have occurred in such a way as to show a general recognition that a legal obligation or rule of law is concerned. The Court found that State practice in this case did not meet these requirements. Among other things, the Court pointed out that most State practice was concerned with delimitations involving opposite coasts. As the Court sets out in its judgment, that situation is sufficiently distinct from a delimitation involving adjacent cases, such as was before the Court, as to not constitute a precedent. It can be noted that a number of these cases concerned bilateral agreements between Denmark, the Netherlands and other North Sea coastal States. This included an agreement between Denmark and the Netherlands of 31 March 1966 (604 UNTS 209). This agreement had established an equidistant boundary between the equidistant tripoints with respectively Germany and the United Kingdom.

10 The last part of the judgment is concerned with the formulation of the principles and rules applicable to the delimitations between respectively Denmark and Germany and the Netherlands and Germany. The Court stressed the point that the parties are under an obligation to enter into negotiations with a view to arriving at an agreement. This implied an obligation so to conduct themselves that the negotiations are meaningful, which would not be the case when either of them insists upon its own position without contemplating any modification of it. The Court found that the negotiations that had been conducted so far had not satisfied these conditions. New negotiations had to take place on the basis of the judgment of the Court.

11 The parties were found to be under an obligation to effect the delimitation of their continental shelf by agreement in accordance with equitable principles, and taking into account all the relevant circumstances. Such a delimitation is to leave, as much as possible, to each party all those parts of the continental shelf that constitute a natural prolongation of its land territory, without an encroachment on the natural prolongation of the land territory of the other. If the application of such delimitation leaves an area of overlap, that area is to be divided between them in agreed proportions, or, failing agreement, equally, unless the parties decided on a joint regime. Factors to be taken into account in the negotiations include: $a$ ) the general configuration of the coasts of the parties, as well as the presence of any special or unusual features; $b$ ) so far as known or readily ascertainable the 
physical and geological structure, and resources, of the continental shelf areas involved; and $c$ ) a reasonable degree of proportionality between the extent of the continental shelf areas of each State and the length of its coast measured in the general direction of coastline, account being taken of any other continental shelf delimitation between adjacent States in the same region. The reference to adjacent States has to be understood as referring to Denmark in the case of Germany and the Netherlands and to the Netherlands in the case of Germany and Denmark.

12 The Court pointed out that the application of equitable principles was called for by a rule of law. There was consequently no question of this being a decision $\rightarrow$ ex aequo et bono. The Court further observed that equity does not necessarily imply equality and that there cannot be a question of completely refashioning nature, to, for instance, render the situation of a State with an extensive coastline similar to that of a State with a restricted coastline. In the present case nature had given the three States concerned broadly equal treatment. However, the employment of the equidistance method would deny one of the parties equal treatment, leading to inequity.

\section{Negotiations Following the Judgment}

13 Following the judgment of the Court, the parties returned to the negotiating table. Although the judgment of the Court was seen as a defeat for Denmark and the Netherlands, the negotiations soon showed that Denmark and the Netherlands were not prepared to accept the full extent of its consequences. One of their principal arguments was that Germany's share of the continental shelf could not be more than a possible solution it had presented to the Court. This concerned a sector-measuring some 36,700 square kilometres, compared to the 23,600 square kilometres accruing to Germany if the equidistance method would be applied-which extended to the middle of the North Sea, giving Germany a common boundary with the UK. Denmark and the Netherlands referred to legal as well as political considerations to back up their position. Germany maintained that the claim it had presented during the pleadings was no longer relevant because the German contentions had been rejected by the Court and initially aimed for an area well over 40,000 square kilometres. The main reason for Germany to accommodate Denmark and the Netherlands, and not to insist on a larger role of the judgment of the Court in a settlement, was the recurrent suggestion of its two neighbours that their bilateral relations otherwise would be damaged. Germany was perceptive to this argument due to the continued sensitivities in Denmark and the Netherlands about their occupation by Nazi Germany during World War II.

14 A settlement was reached by a number of concessions that Denmark and the Netherlands each made to Germany. These concessions were largely justified by geological considerations, even though the judgment of the Court indicated the primacy of geography in the delimitations process. Denmark and the Netherlands took this approach because it allowed Germany to be excluded from the areas with the best prospects for hydrocarbons.

15 Under the two bilateral agreements between, respectively, Germany and Denmark of 28 January 1971 and Germany and the Netherlands of the same date, the area of continental shelf of Germany is slightly less than that claimed by Germany before the Court. The continental shelf of Denmark and the Netherlands remained substantially larger. The settlement leaves a number of promising exploratory wells that had been drilled by the Danish concessionaire on the Danish side of the boundary. During the previous negotiations and the proceedings before the ICJ, Danish and Dutch concessionaires had been operating up to the equidistance line under an arrangement that included notification by the Danish and Dutch authorities to their German counterparts. Germany routinely replied that these activities were without prejudice to its position. The agreements of Germany with Denmark 
and the Netherlands settling their continental shelf boundaries also include arrangements in relation to existing rights of concessionaires. This settlement in relation to the Danish and Dutch concessionaires was based on political considerations and was not mandated by the judgment of the Court.

\section{Conclusions}

16 The proceedings before the Court and the judgment assisted the States concerned to reach agreement on the delimitation of their continental shelf. For one thing, the proceedings resulted in a clearly elaborated claim by Germany, which served as a focal point of the subsequent negotiations. Although Denmark and the Netherlands were unwilling to accept the full import of the judgment, the judgment and opinions of individual judges still had an impact on the final outcome of the negotiations. They for instance played a role in securing Germany's access to the centre of the North Sea and made it difficult for Denmark and the Netherlands to maintain that Germany should get significantly less than the claim it had presented to the Court. Such an outcome could not have been justified by the German government in parliament and public opinion with reference to the judgment of the Court.

17 The judgment of the Court in the North Sea Continental Shelf Cases has had a profound impact on the development of maritime delimitation law. The judgment was issued at a time when negotiations on a new Law of the Sea Treaty were getting underway. The judgment pointed out that customary law differed from Art. 6 Continental Shelf Convention, and that the content and impact of this latter provision were uncertain, due to the 'very considerable, still unresolved controversies as to the exact meaning and scope' of the term special circumstances. At the Third United Nations Conference on the Law of the Sea one group of States advocated a delimitation provision giving primacy to equitable principles and another provision referring explicitly to equidistance (see also $\rightarrow$ Conferences on the Law of the Sea). A compromise could only be attained by not including a substantive rule of delimitation law in the articles on the delimitation of the continental shelf and the $\rightarrow$ exclusive economic zone of the UN Convention on the Law of the Sea ( $\rightarrow$ Law of the Sea).

18 The importance the Court attached to the concept of natural prolongation in its judgment led States to make extensive argument concerning the geology and geomorphology of shelf areas as witnessing the existence of two separate shelf areas or as indicating the boundary of their natural prolongation in later cases. The case-law has never accepted such arguments. At least within 200 nautical miles from the baselines such arguments are not of any relevance, neither in verifying title nor in proceeding to a delimitation between States. The judgment of 14 March 2012 of the International Tribunal of the Law of the Sea in Dispute concerning Delimitation of the Maritime Boundary between Bangladesh and Myanmar in the Bay of Bengal (Bangladesh/Myanmar) indicates that the same applies to the delimitation of the continental shelf beyond 200 nautical miles.

19 The observations of the Court on natural prolongation also influenced the negotiations on the definition of the continental shelf at the Third United Nations Conference on the Law of the Sea. Certain coastal States used this concept as one of the arguments to support their claim that the outer limit of the continental shelf is formed by the outer edge of the continental margin. Whether the judgment actually supports that interpretation is open to doubt. 
20 Subsequent decisions of the Court and arbitral tribunals have departed to an important extent from the judgment in the North Sea Continental Shelf Cases. The rule contained in the Continental Shelf Convention and customary international law have been found to be largely similar in content and effect. Similarly, the case-law has concluded that Arts 74 and 83 UN Convention on the Law of the Sea allow applying these same rules. The case-law has also given increased recognition to the significance of equidistance. The Court itself in 1969 had already recognized that equidistance in general provided an appropriate starting point to delimit a continental shelf boundary between opposite States. Recent case-law has indicated that the drawing of a provisional equidistance line-however, at times not taking into account all relevant base-points-is also the appropriate starting point in cases involving adjacent coasts. Next, it has to be checked if there are circumstances that require a shift in the equidistance line to arrive at the boundary. This approach now seems to be firmly established.

\section{Select Bibliography}

E Menzel 'Der Festlandsockel der Bundesrepublik Deutschland und das Urteil des Internationalen Gerichtshofs vom 20. Februar 1969' (1969) 14 Jahrbuch für Internationales Recht 13-100.

F Monconduit 'Affaires du plateau continental de la mer du Nord' (1969) 15 AFDI 213-44.

F Eustache 'L'affaire du plateau continental de la mer du Nord devant la Cour internationale de Justice' (1970) 74 RGDIP 560-639.

W Friedmann 'The North Sea Continental Shelf Cases: A Critique' (1970) 64 AJIL 229-40.

LFE Goldie 'The North Sea Continental Shelf Cases: A Ray of Hope for the International Court' (1970) 16 NewYorkLForum 326-77.

E Grisel 'The Lateral Boundaries of the Continental Shelf and the Judgement of the International Court of Justice in the North Sea Continental Shelf Cases' (1970) 64 AJIL 562-93.

J Lang Le plateau continental de la Mer du Nord (Librairie générale de droit et de jurisprudence Paris 1970).

K Marek 'Le problème des sources du droit international dans l'arrêt sur le plateau continental de la mer du nord' (1970) 6 RBDI 44-78.

T Rothpfeffer 'Equity in the North Sea Continental Shelf Cases' (1972) 42 Nordisk Tidsskrift for International Ret 81-137.

SC Chaturvedi 'The North Sea Continental Shelf Cases Analysed' (1973) 13 IJIL 48193.

A Reynaud Les différends du Plateau continental de la Mer du Nord devant la Cour Internationale de Justice (Librairie Générale de Droit et de Jurisprudence Paris 1975). RY Jennings 'The Principles Governing Marine Boundaries' in K Hailbronner G Ress and T Stein (eds) Staat und Völkerrechtsordnung (Springer Berlin 1989) 397-408. P Weil The Law of Maritime Delimitation (Grotius Cambridge 1989).

ED Brown Sea-Bed Energy and Minerals: The Continental Shelf vol 1 (Nijhoff Dordrecht 1992) 50-87.

R Kolb Case Law on Equitable Delimitation (Nijhoff The Hague 2003) 20-84. AG Oude Elferink The Delimitation of the Continental Shelf between Denmark, Germany and the Netherlands: Arguing Law, Practicing Politics? (CUP Cambridge 2013). 


\section{Select Documents}

Agreement between Denmark and the Netherlands concerning the Delimitation of the Continental Shelf under the North Sea between the Two Countries (with annexed map) (signed 31 March 1966, entered into force 1 August 1967) 604 UNTS 209. Agreement (with Protocol) between Denmark and the Federal Republic of Germany concerning the Delimitation, in the Coastal Regions, of the Continental Shelf of the North Sea (signed 9 June 1965, entered into force 27 May 1966) 570 UNTS 91. Delimitation of the Maritime Boundary between Bangladesh and Myanmar in the Bay of Bengal (Bangladesh/Myanmar) ITLOS Case No 16 (14 March 2012). North Sea Continental Shelf (Federal Republic of Germany $v$ Denmark and Federal Republic of Germany $v$ Netherlands) (Merits) [1969] ICJ Rep 4.

North Sea Continental Shelf (Federal Republic of Germany v Denmark and Federal Republic of Germany v Netherlands) [1968] ICJ Pleadings vols I-II.

Treaty between Denmark and the Federal Republic of Germany concerning the Delimitation of the Continental Shelf under the North Sea (with Annexes and Exchanges of Letters) (signed 28 January 1971, entered into force 7 December 1972) 857 UNTS 109.

Treaty between the Netherlands and the Federal Republic of Germany concerning the Lateral Delimitation of the Continental Shelf in the Vicinity of the Coast (signed 1 December 1964, entered into force 18 September 1865) 550 UNTS 123.

Treaty concerning the Delimitation of the Continental Shelf under the North Sea (with Annexes and Exchanges of Letters) between the Netherlands and the Federal Republic of Germany (signed 28 January 1971, entered into force 7 December 1972) 857 UNTS 131. 